\title{
Verbal Argument Structure in the War Scroll
}

\author{
John Screnock \\ University of Oxford, Oxford, UK \\ john.screnock@orinst.ox.ac.uk
}

\begin{abstract}
This essay presents the results of an extended study of verbal argument structure in the War Scroll (1QM). I first establish a method based in generative linguistic theory. I then illustrate this method with a discussion of the argument structure of Qal יצא in $1 \mathrm{QM}$ and other Dead Sea Scrolls. Following this case study, I present the data from 1QM on verb argument structure - specifically, instances where $1 \mathrm{QM}$ adds evidence that is not covered in previous studies of the Dead Sea Scrolls. 1QM presents few developments from earlier Hebrew; I argue that such continuity is significant. I conclude with reflections on the implications of argument structure in $1 \mathrm{QM}$ for the study of ancient Hebrew.
\end{abstract}

\section{Keywords}

Hebrew - War Scroll (1QM) - argument structure - valency - verb complementation יצא

\section{$1 \quad$ Introduction}

This study presents the results of an extended survey of verbal argument structure in the War Scroll (1QM). After articulating a method based in generative linguistic theory, I discuss an example case from my corpus. I then present the general data, highlighting where $1 \mathrm{QM}$ adds evidence not covered in previous studies of the Dead Sea Scrolls. Finally, I conclude with some reflections on implications for the study of Hebrew-specifically, the value of an analysis showing that the Hebrew of the Scrolls does not differ much from earlier Hebrew. I have considered and compiled data for the argument structure of all verbs occurring five times or more in $1 \mathrm{QM}$. The end of this analysis of ${ }_{1} \mathrm{QM}$ 
marks the beginning of broader considerations that place 1QM's data in the context of all the Scrolls and the even larger context of ancient Hebrew's development over time. Both of these steps are necessary: beginning with a narrow analysis in just one text-in order not to lose the trees-and from that basis going to a broader view of the forest. ${ }^{1}$

\section{$2 \quad$ Linguistic Framework and Method}

The concept of a verb's "argument structure" is similar to "verb complementation," "verb valency," and "transitivity." A number of scholars have considered verbal argument structure in ancient Hebrew. Takamitsu Muraoka, ${ }^{2}$ Michael Malessa, ${ }^{3}$ and John Cook $^{4}$ published dedicated studies to the issue that take the Hebrew of the Bible as the main point of departure; the recent contributions by Malessa and Cook are based on the perspectives of Dependency Grammar and Generative Linguistics, respectively. Many reference grammars include discussions of verb complementation ${ }^{5}$ - often under the guise of discussing the "accusative" - while recent volumes in the Baylor Handbook on the Hebrew Bible address the theory of argument structure and apply it to particular texts from the Hebrew Bible. ${ }^{6}$ Also of note is the nine-volume Dictionary of Classical Hebrew, ${ }^{7}$ which includes extensive data on lexemes and parts of speech that frequently occur with verbs (though not set within an explicit argument structure framework), including in the Dead Sea Scrolls. Discussions of argument structure in the Hebrew of the Dead Sea Scrolls can be found in Qimron's reference grammar ${ }^{8}$ and Muraoka's "Morphosyntax and Syntax of Qumran Hebrew."9 Studies dedicated to argument structure in the Scrolls have been presented by Muraoka-who catalogues the complements of verbs in ${ }_{1 \mathrm{QS}}, 1 \mathrm{QSa}, 1 \mathrm{QSb}$, and $1 \mathrm{QH}$, with further discussion of particular cases $^{10}$ —and

$1 \quad$ On this point, see Holmstedt and Screnock, "Noun Phrase," 67-69. The present study stems from the larger project on $1 \mathrm{QM}$ described in "Noun Phrase."

$2 \quad$ Muraoka, "Verb Complementation in Biblical Hebrew."

3 Malessa, Untersuchungen zur verbalen Valenz; idem, "Valency."

4 Cook, "Valency."

5 E.g., Van der Merwe, Naudé, and Kroeze, Biblical Hebrew Reference Grammar, §33.

6 E.g., Holmstedt, Ruth, 4-8 and throughout; Screnock and Holmstedt, Esther, $2-5$ and throughout; Holmstedt, Cook, and Marshall, Qohelet, 6-8 and throughout.

7 Clines, Dictionary of Classical Hebrew.

8 Qimron, Hebrew of the Dead Sea Scrolls, 400-406.

9 Muraoka, "Morphosyntax and Syntax of Qumran Hebrew," 202-206.

10 Muraoka, "Verb Complementation in Qumran Hebrew." 
Rey — who focuses on the use of bet to mark "objects" of the verb in the Dead Sea Scrolls."1

In my analysis of verbal argument structure, I follow generative linguistics instead of traditional grammar. ${ }^{12}$ As a result, I use terms and concepts like complement, argument structure, and theta-role, instead of concepts like indirect object, direct object, and transitivity. ${ }^{13}$ Depending on the verb being used, the verb phrase may require other constituents to complete the verb phrase. These constituents are complements - in contrast to adjuncts, which are not required. Complements can be noun phrases (NPs), but are often other types of phrases such as prepositional phrases (PPs). ${ }^{14}$ Besides complements, most verbs also require subjects. The requirements of each specific verb for certain arguments (subjects and complements) is its argument structure. To a native English speaker, for example, the phrases "I hit" (without any further context) and "hits the ball" are ungrammatical. The phrase "she hits the ball," on the other hand, is grammatical, because it contains all the necessary arguments. Arguments can be null/covert, as in the following example (with its preceding context): "Did she go to the lecture? Yes, she went." In the second sentence, the phrase "to the lecture" is null/covert. The fact that a particular type of phrase is used often with a verb does not entail that such a phrase is a required argument; the phrase may be adjunct to the verb. Verbs are not the only words that take argument structure; adjectives, for example, can require complements. ${ }^{15}$

11 Rey, "Prepositional Object with bet." On Rey's concept of object, see footnote 13.

12 See Carnie, Syntax, 228-36; Cowper, Syntactic Theory, 48-55; Aarts, English Syntax and Argumentation, 94-99.

13 The notion of "object" - the thing acted upon in a predication —is more about syntax than about the semantics and argument structure of the verb; the subject of a passive verb is not its object, though it is the thing acted upon (e.g., "the car was washed"). As John Cook has noted, analyses of Hebrew based on these kinds of categories result in descriptions that are possibly misleading: "the transitivity approach of traditional grammar leads to awkward discussions about so-called accusative noun phrases that function as something other than direct object and other 'objects' of the verb as mediated by prepositions;" Cook, "Valency," 55. Such approaches are commonly applied in the study of Biblical Hebrew and Dead Sea Scrolls Hebrew; e.g., Rey: "In 4QInstruction the syntagma רז נהיה is almost always governed by the preposition ב ב when it is the object of verbs such as [נבט,לקח,הגה ,גלה]"; "Prepositional Object with bet," 189 .

14 Cook, "Valency," 55-56.

15 See Lowe, Transitive Nouns and Adjectives. Examples of such adjectives in English include ready (for something/to do something), near (someone or something), and desirous (of something). 

(1) *I hit.
(9) *I walked my mother.
(2) I hit the ball.
(10) I walked my mother home.
(3) *I walked.
(11) *I went the sky.
(4) *Walked to the store.
(12) I went to the store.
(5) I walked to the store.
(13) I went for a run.
(6) I walked home.
(7) On Sundays, I walk.
(14) *Tim sold.
(8) I walked my dog.
(15) Tim sold his saxophone.
(16) Tim sold me his saxophone.

* = ungrammatical

FIGURE 1 Some examples from English

Because a verb's argument structure typically includes subjects, not just complements, ${ }^{16}$ I avoid the term "complementation" as a way of referring to the entire phenomenon. ${ }^{17}$ I also avoid "valency" and related terms ("monovalent," "bivalent," etc.) because they are redundant with "argument structure" and related terms ("requiring one argument," "requiring two arguments," etc.).

Argument structure depends on the semantics of the lexemes involved. ${ }^{18}$ This is most apparent for the verb, where the number and type of arguments depends on the meaning of the verb. The ability of an argument to fulfill its role also depends on semantics - the argument's semantics. "I walked to the store," for example, is grammatical, but "East walked to compassion" is notdespite the same number of arguments being present in the same syntactic constructions (subject, PP). The concept of thematic relations accounts for the semantic aspects of argument structure (see the table of thematic relations in Figure $2^{19}$ ). The verb "to walk" requires a complement, but not just any complement: it must be a complement whose thematic relationship to the verb is LOCATION. Similarly, the subject required by "to walk" must have the thematic relationships of both AGENT and THEME. Argument structures require these thematic relations to be present; because different parts of speech can take the same thematic relation, argument structure is not about the requirement for particular parts of speech..$^{20}$

16 The use of different binyanim in Hebrew, moreover, causes significant overlap between the two.

17 Note that in some linguistic theories, the subject is referred to as a complement; Malessa, "Valency," 895.

18 Cf. Malessa, "Valency," 893.

19 Adapted from Cowper, Syntactic Theory, 48-51.

20 For example, one can "walk to the store" (PP) or "walk home" (NP); one can יעשה כאשר 
There is not a one-to-one relationship between thematic relations and a verb's argument structure. ${ }^{21}$ In the phrase "Tim sold me his saxophone," "Tim" is both AGENT and SOURCE, while "his saxophone" is PATIENT and GIFT. Moreover, a single argument might be allowed to take one thematic relation out of several options: the verb "to go," for example, requires a complement that can be either a LOCATION or a GOAL: I went to the store and I went for a run. ${ }^{22}$ Because thematic relations do not map isomorphically onto argument structure, generativists have posited the theta-role: the bundle of possible thematic relations assigned to one position in a verb's argument structure. ${ }^{23}$ Each argument of the verb has one theta-role. For convenience, theta-roles are often referred to by the most prominent thematic relation in that theta-role. In "Tim sold me his saxophone," "Tim" is both AGENT and SOURCE, but fills just one theta-role, which we could call the AGENT theta-role. In the discussion that follows, I will refer to arguments using thematic-relation terms like AGENT, PATIENT, and GOAL, as shorthand terms for theta-roles. In my analysis of argument structure in $1 \mathrm{QM}$, what I am ultimately after is the identification of thetaroles. I still pay attention to what parts of speech these theta-roles take (e.g., LOCATION as NP, ל-PP, על-PP, etc.); the differences in such cases, however, are not differences in argument structure - they are semantic nuances. ${ }^{24}$

Though further conceptual nuance has been developed to describe verbal argument structure, ${ }^{25}$ the model I have just sketched is sufficient for our purposes. A few more points will help to clarify what I aim to accomplish (and what I do not aim to accomplish) in this study. First, verbs-whether in ancient Hebrew or modern languages - are used in various ways, with and without different types of arguments. ${ }^{26}$ "I sold my car" (two arguments) and

יעשה כן ("act according to what the LORD said"; PP complement) or thus"; adverb complement). This point marks a major point of difference between my study and past studies of argument structure in the Scrolls; Muraoka's "Verb Complementation in Qumran Hebrew," for example, lists complements by their part of speech, not their thematic relation or theta-role. On the distinction between syntactic role and thematic relation, as well as the place of semantics in argument structure, cf. Aarts, English Syntax and Argumentation, 97-99; Qimron, Hebrew of the Dead Sea Scrolls, 428.

21 Cowper, Syntactic Theory, 51.

22 Hebrew verbs of motion (בוא בוא : בוא usually takes a LOCATION complement-whether a PP or NP—but the same role can also be fulfilled by a GOAL.

23 Carnie, Syntax, 233-34; Cowper, Syntactic Theory, 55.

24 Muraoka's semantic distinction between בוא לוא ב ("approach") ander"), for example, does not entail a difference in argument structure; "Verb Complementation in Qumran Hebrew," 110, n33.

25 See, e.g., Jackendoff, "Thematic Relations."

26 Cf. Malessa, "Valency," 895. 
AGENT-entity that initiates or does an action

INSTRUMENT - entity with which an action is performed PATIENT-entity that undergoes an action

CAUSE - entity that makes an AGENT initiate or do an action

GOAL - end result of action (including a verb of motion)

LOCATION-entity in or toward which motion takes place

SOURCE - entity from which motion/transaction takes place

THEME - entity that moves with a verb of motion

RECIPIENT - entity on the receiving end of a transaction

GIFT-entity that changes possession in a transaction

EXPERIENCER-entity that undergoes or perceives the event or state of being

PERCEPT-entity that is experienced or perceived

BENEFACTIVE-entity for whose benefit the event takes place

FIGURE 2 Some thematic relations

"I sold Becky my car" (three arguments) are both grammatical; similarly, "I walked to the store" (with a LOCATION complement), "I walked my dog" (with a PATIENT/THEME complement), and "I walked my mother to the store" (with LOCATION and PATIENT/THEME complements) are all grammatical. Though these variations are possible, this does not entail that there are no rules governing the argument structures of "to sell" and "to walk." Given various aspects of context and the semantics of the individual words, these verbs take specific argument structures in each case, entailing ungrammaticality if the argument structure is contravened.

Second, argument structure is one of the more difficult aspects of language to access in a dead language. Because arguments of the verb are often null/covert, native-speaker grammaticality judgments are crucial for determining argument structure with certainty. ${ }^{27}$ Given our lack of access to native speakers of ancient Hebrew, we must tread carefully and recognize the limits of our investigation. Hard and fast rules for determining argument structure based on ancient Hebrew evidence are inadvisable. A single token, for example, may show us a grammatical instance of the argument structure of a verb; and though it only occurs once, such an analysis may be preferable to positing a mistake, corruption, or a completely different meaning for the verb. Although we cannot make grammaticality judgements, this does not negate the reality that there was grammaticality in ancient Hebrew-like any living, spoken lan-

27 Thus, I use English examples throughout in this section on method. 
guage. To the native speaker of ancient Hebrew, grammaticality mattered, and we must account for this in terms of our theory.

\section{$3 \quad$ Analysis}

In this section, I begin with an example (יצא) that illustrates my approach, and then present and discuss my data for all verbs in $1 Q \mathrm{M}$. As noted above, studies of argument structure in the Hebrew of the Scrolls have been published by Muraoka, Qimron, and Rey. ${ }^{28}$ Because the points addressed by Qimron and Rey are peripheral to my focus in $1 \mathrm{QM},{ }^{29}$ my main point of departure in terms of past scholarship is Muraoka's "Verb Complementation in Qumran Hebrew." Muraoka's study is, moreover, the most comprehensive existing treatment. The corpus of Muraoka's "Verb Complementation in Qumran Hebrew" mainly consists of $1 \mathrm{QS}, 1 \mathrm{QSa}, 1 \mathrm{QSb}$, and $1 \mathrm{QH} .{ }^{30}$

\subsection{The Argument Structure of $\mathrm{N}$}

Qal יצא is one of the few verbs treated by Muraoka for which I disagree with Muraoka's analysis. Although Muraoka's "Verb Complementation in Qumran Hebrew" lists complements by part of speech rather than theta-roles, ${ }^{31}$ his entry on Qal יצא indicates a particular understanding that can be contrasted with mine. Muraoka gives one type of complement: מלפני a-PP, indicating the

28 See footnotes $8-11$.

29 The phenomena discussed by Qimron are not factors in 1QM; though he discusses verbs of motion and the indication of location (Hebrew of the Dead Sea Scrolls, 403-404), it is not in terms of complementation or argument structure. The verbs addressed by Rey occur fewer than five times in $1 \mathrm{QM}$, though the semantics of $ב$ play a role in some of my data. Rey's point of departure is the fact that רז נהיה almost always occurs in a ב-PP in 4QInstruction "when it is the object" of six "verbs of instruction" (בכר , נבט,ידע,גלה ,לקח, and בין); "Prepositional Object with bet," 189. He then seeks to explain these uses as developments in verb complementation, analyzing the use of ב-PPs with these verbs throughout the Dead Sea Scrolls. Generally speaking, I might prefer to analyze the phenomena Rey discusses in terms of the semantics of ב, rather than the argument structure of the verbssince (in my methodology) a PATIENT is a PATIENT whether it is a NP or a ב-PP; cf. the discussion of נפל in section 3.2. In his discussion of גלה, Rey argues that ב ב ב ב ב instrument but instead the thing "revealed"; 209. The thesis in this case seems to require a development in the semantics of the verb גלה, from "to uncover [something]" to "to reveal [something] to [someone]" (a new lexical entry).

30 Related texts from Cave Four are also cited at relevant points, as are other texts sporadically (e.g., CD).

31 See section 2 above, esp. footnote 20. 
TABLE 1 Data for Qal יצא (in 1QHa, 1QM, 1QS, 1QSa, and 1QSb)

\begin{tabular}{|c|c|c|}
\hline & No LOCATION/GOAL & LOCATION/GOAL \\
\hline No SOURCE & $\begin{array}{l}{ }^{1 Q M} 3: 1^{\mathrm{GS}} ; 6: 1^{\mathrm{G}}, 4^{\mathrm{G}}, 9^{\mathrm{G}} ; 16: 4^{\mathrm{GS}}, \\
8 ; 1 \mathrm{QS} 6: 16^{\mathrm{GS}} ; 1 \mathrm{O}: 13\end{array}$ & $\begin{array}{l}\text { 1QM 1:4, 13; } 2: 8(\times 2) ; 3: 7^{\mathrm{S}} ; 4: 9 ; \\
6: 11-12 ; 7: 14 ; 8: 10-11 ; 16: 12 ; \\
{ }_{1 Q S} 4: 19 ; 5: 3^{\mathrm{S}} ; 6: 18-19^{\mathrm{S}}, 21-22 ; \\
9: 7-8^{\mathrm{S}}, 1 \mathrm{Q} \text { Sa } 1: 16,17\end{array}$ \\
\hline SOURCE & $\begin{array}{l}\text { 1QM 7:16, } 17 ; 8: 3-4^{\mathrm{G}} ; 9: 12-13 \\
{ }_{1} \mathrm{HH}^{\mathrm{a}} 4: 31\end{array}$ & $\begin{array}{l}\text { 1QM 7:3-4, 9, 13-14;9:3-4, 11; } \\
{ }_{1 Q S} \text { 7:23-24; 9:9-10 }\end{array}$ \\
\hline
\end{tabular}

G a covert LOCATION/GOAL is very possible

$\mathrm{s}$ a covert SOURCE is very possible

point of departure (a sou RCE theta-role). ${ }^{32}$ He does not list any parts of speech or give any examples where the destination is in view (a LOCATION or GOAL theta-role). ${ }^{33}$

The data from $1 \mathrm{QM}$ and from Muraoka's corpus (1QS, $1 \mathrm{QSa}, 1 \mathrm{QSb}$, and $1 \mathrm{QH})$, however, suggest that his analysis is incorrect or at least not representative (see Table 1). In 1QM, יצא regularly occurs with constituents indicating a LOCATION or GOAL: one goes out for battle, or goes out to a certain position. ${ }^{34}$ In cases where there is no LOCATION or GOAL overt, it is not difficult to reconstruct from context what the LOCATION or GOAL is, and sometimes context demands it. The question is whether the verb requires a complement of this type - a LOCATION/GOAL argument (I use "LOCATION/GOAL" as shorthand for the theta-role fulfilled by a LOCATION or a GOAL) — or whether these are simply adjuncts to the verb. Looking beyond $1 \mathrm{QM}$, there are just six places in $1 \mathrm{QH}, 1 \mathrm{QS}, 1 \mathrm{QSa}$, and 1QSb where a clause with יצא does not have an overt LOCATION/GOAL or easily allow for a covert LOCATION/GOAL. Consider Muraoka's example for G יצא, in 1QS 7.23: ויצא מלפני הרבים, "he will go out from before the many." Immediately

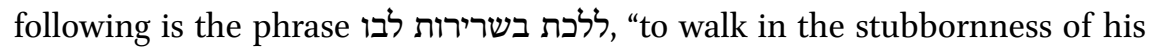
heart." Muraoka's understanding of יצא בשת מירות would take the infinitive phrase to be an adjunct to the verb; given the widespread use of LOCATION/GOAL phrases in the Scrolls, however, this phrase can be understood as a complement.

32 Muraoka, "Verb Complementation in Qumran Hebrew," 121-22.

33 יצא יצא Though I am focusing here on Q יצא also does not give any such phrases or examples as complements.

34 Many verbs of motion take LOCATION or GOAL complements; in 1QM, these include tD עמד , עב , קרב and G and tD. 
In my view, then, יצא's main argument structure in the Hebrew of the Scrolls requires a THEME (the person or thing going out) and a LOCATION/GOAL (the place to which they go out or the goal of going out), with no requirement for a soURCE. Given the problems inherent in analyzing argument structure in a dead language (see section 2), I hold loosely to this particular analysis of יצא as requiring a LOCATION/GOAL complement. It is also important to note that other argument structures, though not the mainly used structure, are in use (see below).

One brief passage, $1 Q M 7 \cdot 9,13-14$, provides a good example of the use of יצא in 1 QM. The LOCATION/GOAL and SOURCE arguments are bracketed for clarity and labelled with $\leftarrow$ and $\leftrightarrow$, respectively.

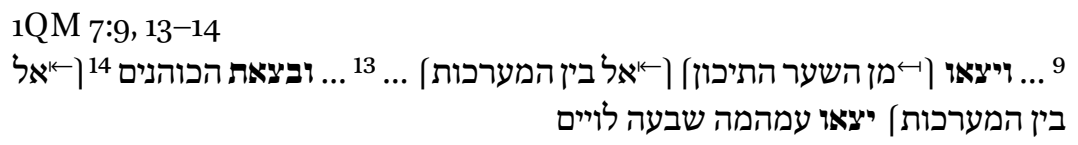

9 ... they shall go out $\int_{\leftarrow}$ from the middle opening $\int_{k}$ into the space between the battle lines| ... ${ }^{13}$... When the priests go out ${ }^{14} \int_{k}$ into the space between the battle lines|, seven Levites shall go out with them. (translation based on WAC $)^{35}$

In line 9, מן is used with an overt-PP source- מן השער התיכון, "from the middle gate"-and אל-PP LOCATION/GOAL— אל בין המערכות, "to a-place-thatis-between the battle lines." In 7:13-14, the verb is used two more times; in neither case is the SOURCE overt, and only once is the LOCATION/GOAL overt (אל בין המערכות). However, given the context, the audience clearly knows that the SOURCE and LOCATION/GOAL are the same as in line 9. Indeed, it would be redundant to state them again overtly. With the words "when the priests go out into the space between the battle lines," the reader assumes from the middle gate; similarly, with the words "seven Levites will go out," the reader assumes from the middle gate, to the place between the battle lines. From a generative perspective, these constituents are truly present in the syntax, even though they are null/covert.

In 1 QM 7:9, 13-14, and in most instances of יצ in 1QM, context suggests that the point of arrival is in focus, not the point of departure. In the language of $1 \mathrm{QM}$ and possibly $1 \mathrm{QH}, 1 \mathrm{QS}, 1 \mathrm{QSa}$, and ${ }_{1 \mathrm{QSb}}$, then, יצא can take an argument structure that requires a THEME and a LOCATION/GOAL, without a SOURCE. ${ }^{36}$

35 Translations are mine unless noted otherwise.

36 This judgement depends on how willing I am to presume a null sourCE in many placesothers may make a different judgement as a result. 
Though this looks like the dominant argument structure, another argument structure (on which see below) is also used in a few cases-requiring a THEME and SOURCE with no other complements. ${ }^{37}$

When we consider earlier periods of Hebrew, reflected in the Hebrew of the Bible, we find that there, too, Qal יצא often takes a LOCATION/GOAL complement. A full-scale analysis of 'צ's argument structure in the Hebrew of the Bible is outside the scope of this study; however, a survey of the evidence and the lexicons is generally conclusive on the following point. Though semantically the lexeme indicates an action involving departure, ${ }^{38}$ the verb's complement is not always the point of departure (SOURCE); the point of arrival (LOCATION) or purpose of departure (GOAL) are also prevalent as complements.

There seem to be at least two argument structures in use for Qal יצא in the Hebrew Bible (as in many of the English examples in Figure 1 above). In the first, the verb requires a subject and a souRCE complement; in the second, the complement is a LOCATION/GOAL instead of a SOURCE. ${ }^{39}$ Examples where יצא takes a SOURCE complement with no further complements include the following. ${ }^{40}$

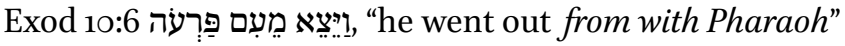

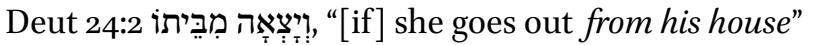

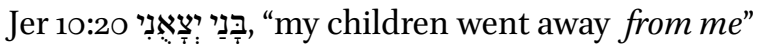

The final example is particularly telling; for a phrase indicating SOURCE to be cliticized to the verb, it is almost surely a complement (rather than adjunct) to the verb. ${ }^{41}$

Examples where יצא takes a LOCATION/GOAL complement with no further complements include the following. ${ }^{42}$

37 See the cases in Table 1 with no overt LOCATION/GOAL and unlikely to have a covert LOCATION/GOAL.

38 See Polak, "Verbs of Motion in Biblical Hebrew," 175-77.

39 Other possible argument structures include: subject but no complements (e.g., $2 \mathrm{Chr} 21: 15$ ); and subject with two complements (sOURCE and LOCATION/GOAL; e.g., Gen 11:31). The former seems likely; in examples of the latter, it seems more likely that either the SOURCE or LOCATION/GOAL is an adjunct, i.e., one of the argument structures discussed in the body of this essay.

40 Further examples include Gen 10:14; Lev 22:4; Num 22:5; Judg 3:19; 1 Kgs 20:17.

41 The interpretation "my children went out to $m e$ " is impossible in context.

42 Further examples include Gen 12:5; Exod 21:2; Lev 14:3; Num 33:54; 1 Sam 13:23; and cases of the idiom "go out for battle," e.g., in Deut 20:1; 21:10; Judg 3:10; 20:14, 20, 28; 2 Sam 21:17; 1 Kgs 8:44 (par. 2 Chr 6:34); 20:18. 


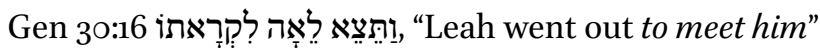

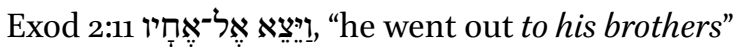

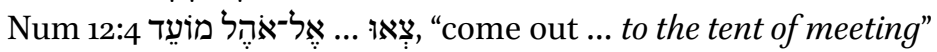

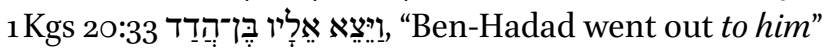

Because Hebrew lexicons do not explicitly address argument structure and complementation, it is impossible to do more than intuit what argument structure(s) might be behind their semantic analyses. Even so, the lexicons give an understanding of Qal יצא that is compatible with the two argument structures I define above. The first paragraph of BDB's entry on יצא יצא uses with a SOURCE (מן-PP). ${ }^{43}$ The second paragraph, though much smaller than the first, is entirely focused on uses with a destination (LOCATION) specified. ${ }^{44}$ HALOT does not provide much access to the types of complements most often appearing with Qal יצא, nor the distinction of cases focused on departure versus those focused on destination. ${ }^{45}$ Nevertheless, HALOT's entry cites some examples with PPs that clearly fit the SOURCE or the LOCATION/GOAL analysis. $D C H$ cites extensive data on what types of PP are used with יצא ${ }^{46} \mathrm{We}$ should not equate particular parts of speech with particular theta-roles (see section 2). However, in most of the cases $D C H$ cites with a מן-PP, the מן-PP indicates a SOURCE and is often a complement. Similarly, many cases with ל-PPs, אל-PPs, על-PPs, and directional indicate a LOCATION/GOAL, and a good number of these are complements rather than adjuncts. While $D C H$ 's main gloss for this section, "go out from," seems to suggest a required sourCE, the frequency of ל-PPs, אל-PPs, על-PPs, and phrases with directional ה is striking; there are about 2.25 columns on these, compared to 1.75 columns for מן לPs. In summary, the evidence presented in these lexicons supports the analysis of Qal יצא as employing at least two argument structures in the Hebrew of the Bible-one with a SOURCE complement, and another with a LOCATION/GOAL complement. ${ }^{47}$

43 Brown, Driver, and Briggs, Brown-Driver-Briggs Lexicon, יצָיָ Qal 1; the section also includes cases of Qal יצא with no complements. Cf. יצָא Hiph. 1, which similarly cites many cases with מן-PPs.

44 Brown, Driver, and Briggs, Brown-Driver-Briggs Lexicon, יָָָ Qal 2; and note the main gloss for the second paragraph, "go forth to a place".

45 Koehler, Baumgartner, and Stamm, Hebrew and Aramaic Lexicon of the Old Testament, יצא Qal.

46 Clines, Dictionary of Classical Hebrew, יצא Qal 2.

47 John Cook, in his unpublished database on verb argument structure in the Hebrew Bible, understands phrases that give "destination" (LOCATION/GOAL) or "origin" (SOURCE) to be 
When we set the evidence from the Dead Sea Scrolls in the context of earlier Hebrew, it is important to consider how stylistic and other factors play a role in shaping the evidence. ${ }^{48}$ Critically, the prevalence of LOCATION/GOAL complements in $1 \mathrm{QM}$ and $1 \mathrm{QS}$ (where most of the data is found) is conditioned by the specific contents of those texts: soldiers going to battle, and initiates joining a group. If we instead had evidence of יצא from texts that discussed other topics-laws for bodily emissions, for example-the argument structure with a SOURCE complement would likely be more prevalent. Using Judg 20-another text that describes soldiers going to battle-as a point of comparison, we find similar patterns of complementation for 4.49 The particular language use in the Dead Sea Scrolls does not transparently reflect the language system that lies behind the text: the balance of one argument structure versus the other in the data does not mean the same balance exists in the language. Though they are much fewer, cases of יצא in the Scrolls with a SOURCE and no LOCATION/GOAL likely represent an argument structure that was common and grammatical in the language system. Comparing the overall picture in the Dead Sea Scrolls to the overall picture in the Hebrew Bible, the argument structure with SOURCE makes up a much larger proportion of cases in the latter than in the former. This difference does not, however, reflect a diachronic change; rather, the texts from the Scrolls that make up our data set just happen to address topics that more often require the LOCATION/GOAL argument structure of יצא.

In summary, it appears that Qal יצא has a well attested argument structure where a LOCATION/GOAL argument is required, in contrast to Muraoka's entry with an argument structure only a SOURCE is required. Both argument structures are evidenced in $1 Q M$, other Scrolls, and in the Hebrew Bible. The example of Qal יצא demonstrates that profiling verbal argument structures in one particular text is an important task. It can provide important information about diachronic development (both evidence for and against development), and it can illuminate synchronic variety of which we previously were not aware.

adjuncts. Thus, the verb's only argument for Cook is the subject; Cook, "Verb Valency Lexicon," יצא. At the same time, he notes that "destination" is more frequently specified than "origin."

48 Screnock, "Hebrew Diachrony," 792.

49 Cases of יצא with a LOCATION/GOAL complement: Judg 20:14, 20, 25, 28, 31. Cases of with a SOURCE complement: Judg 20:21, 25 . 


\subsection{The Argument Structure of Other Verbs in $1 Q M$}

The evidence from $1 \mathrm{QM}$ adds new verbs, binyanim, and argument structures that do not appear in Muraoka's "Verb Complementation in Qumran Hebrew"; these are presented in Table $2 .{ }^{50}$

TABLE 2 Argument structures not present in Muraoka's database

\begin{tabular}{|c|c|c|c|c|}
\hline Root & binyan "gloss" (example) & Total & Argument structure & \\
\hline \multirow[t]{2}{*}{ אור } & G "to shine" (1.8) & 1 & AGENT NP & \\
\hline & $\mathrm{H}^{+}$"to shine" $(5.10)$ & 3 & AGENT NP & \\
\hline אמר & $\mathrm{G}^{+}$"to say" (14.4) & 5 & AGENT NP & PATIENT clause (direct-speech) \\
\hline \multirow[t]{2}{*}{ 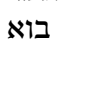 } & $\mathrm{G}^{+}$"to come" $(3.11)$ & 10 & THEME NP & LOCATION NP or PP (עד ,ב ,ל,אל) \\
\hline & $\mathrm{H}^{+}$"to bring" $(7.11-12)$ & 3 & CAUSE NP & THEMENP אל LOCATION-PP \\
\hline 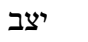 & tD "to take one's stand" (2.5) & 6 & AGENT NP & LOCATION PP (ל , , , על) \\
\hline \multirow[t]{3}{*}{ ירא } & G "to be afraid" & 2 & EXPERIENCER NP & \\
\hline & G "to fear" (17.4) & 1 & AGENT NP & PATIENT NP \\
\hline & $\mathrm{N}$ "to be feared" (12.7) & 2 & PATIENT NP & \\
\hline 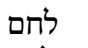 & $\mathrm{N}$ "to fight" (1.2) & 11 & AGENT NP & PATIENT ב-PP52 \\
\hline \%מד & Dp "to be taught" (6.12) & 3 & AGENT NP & PATIENT NP \\
\hline \multirow[t]{2}{*}{ 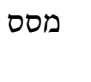 } & N “to despair” (11.9) & 2 & EXPERIENCER NP & \\
\hline & H “to discourage" (9.11) & 3 & CAUSE NP & EXPERIENCER NP \\
\hline \multirow[t]{2}{*}{ 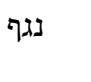 } & G "to strike" (3.9) & 2 & AGENT NP & PATIENT NP \\
\hline & N "to be struck down" (17.15) & 4 & PATIENT NP & \\
\hline \multirow[t]{2}{*}{ 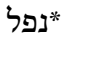 } & G "to fall" (9.7) & 10 & AGENT NP & \\
\hline & $\mathrm{H}^{+}$"to fell" (16.8) & 4 & AGENT NP & PATIENT ב-PP \\
\hline \multirow[t]{2}{*}{ 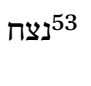 } & $\mathrm{D}$ "to direct" (9.2) & 7 & AGENT NP & PATIENT NP \\
\hline & tD "to be directed" (17.15) & 2 & PATIENT NP & \\
\hline \multirow[t]{2}{*}{ 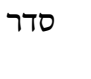 } & Gp "to be arranged" (5.4) & 1 & PATIENT NP & \\
\hline & D "to arrange" $(15.5)$ & $5^{54}$ & AGENT NP & PATIENT NP \\
\hline
\end{tabular}

50 Muraoka's interest is in verbal complements, whereas I am interested in the argument structure of verbs-a slight difference, but as a result, Muraoka's database does not include verbs and binyanim that take zero complements, whereas I include these. Qal יצא, discussed in section 3.1, is not included in my table because it already appears in Muraoka, "Verb Complementation in Qumran Hebrew."

$5^{1}$ Both instances of this argument structure derive from the language of Deut 20:3 (once in a quote, once in an allusion).

52 Once (10.4) with PATIENT עם-PP in a quote of Deut 20:4; once (1.11) with a compound subject denoting both AGENT and PATIENT (i.e., X and Y fight one another).

53 Here I do not include 12.5, נוֹצים, which I take to be from the homophone נצח, "to shine";

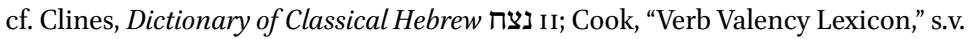

54 I include 5.3, סרך לסדר דגלי המלחמה, where סדר could be understood as a noun or an infinitive. 
TABLE 2 Argument structures not present in Muraoka's database (cont.)

\begin{tabular}{|c|c|c|c|c|}
\hline Root & binyan "gloss" (example) & Total & Argument structure & \\
\hline \multirow[t]{2}{*}{ 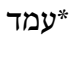 } & G "to stand" (8.6) & 7 & AGENT NP & \\
\hline & G "to stand" (6.8) & 15 & AGENT NP & 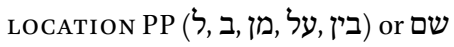 \\
\hline 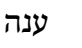 & $\mathrm{G}^{+}$"to respond" (13.2) & 5 & AGENT NP & \\
\hline 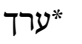 & N "to be waged" (2.9) & 1 & PATIENT NP & \\
\hline 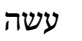 & $\mathrm{G}^{+}$"to act" $(12.11)$ & 7 & AGENT NP & MANNER NP/כ-PP/למען-clause \\
\hline \multirow[t]{2}{*}{ עתד } & Gp "to be prepared" (10.5) & 4 & PATIENT NP & BENEFACTIVE PP \\
\hline & tD "to prepare oneself" $(15.15)$ & 1 & AGENT NP & BENEFACTIVE PP \\
\hline \multirow[t]{3}{*}{ 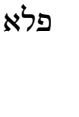 } & $\mathrm{N}$ “to be wonderful” (14.14) & 1 & EXPERIENCER NP & \\
\hline & H "to make wonderful" (14.9) & 3 & CAUSE NP & EXPERIENCER NP \\
\hline & H "to act wonderfully" (18.7) & 1 & AGENT NP & \\
\hline 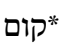 & G "to arise" (18.2) & 5 & THEME NP & \\
\hline 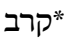 & tD "to bring oneself near" (1.10) & 5 & THEME NP & GOAL ל-PP \\
\hline 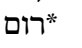 & G "to be high" (14.16) & 4 & EXPERIENCER NP & \\
\hline \multirow[t]{2}{*}{ רוע } & H "to sound" (8.1) & 1 & AGENT NP & \\
\hline & H "to sound" (16.8) & 15 & AGENT NP & PATIENT NP56 \\
\hline \multirow[t]{2}{*}{ 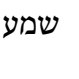 } & $\mathrm{G}^{+}$"to obey" $\left(16.15^{-16}\right)$ & 1 & AGENT NP & PATIENT ב-PP \\
\hline & $\mathrm{H}^{+}$"to cause to listen" (11.11) & 1 & CAUSE NP & PATIENT NP \\
\hline 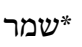 & $\mathrm{N}$ "to guard oneself" (10.1) & 1 & AGENT NP & SOURCE מן מן-PP \\
\hline 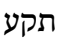 & G "to sound" (8.7) & 16 & AGENT NP & PATIENT NP58 \\
\hline
\end{tabular}

* See Muraoka for the same root in other binyanim

+ See Muraoka for the same binyan with a different argument structure or parts of speech

$\mathrm{G}=$ qal, $\mathrm{Gp}=$ qal pass., $\mathrm{N}=$ niphal, $\mathrm{D}=$ piel, $\mathrm{tD}=$ hitpael, $\mathrm{H}=$ hiphil

55 With עשיתה למען שמכה ,you acted for the sake of your name," the למען-PP fulfils the theta-role typically associated with MANNER: the behavior was the sort that benefits God's name.

56 See footnote 58 on תקע presents the same types of cases and has similar variant analyses.

57 This entry presents one case where Jackendoff's idea of hierarchical theta-roles (see Jackendoff, "Thematic Relations") is better suited than the system I am using, insofar as the thematic relation SOURCE does not fully capture what is happening here (the מן-PP does not denote a location out of which the action takes place); cf. Primus, Cases and Thematic Roles, $5^{\circ}$, on the argument structure of verbs of abstaining.

$5^{8}$ I understand cases with no overt complement (e.g., 1QM 16.13) to refer to generic action and/or to take assumed complements; cf. Cook, "Valency," 61-63, on optional comple-

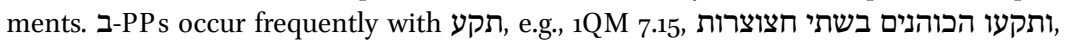
"the priests should sound [a signal] on the two trumpets of ...." It is possible to posit a second argument structure, "to blow [an instrument]," taking a ב-PP complement; moreover, where NP complements and ב-PPs occur together (e.g., 1QM 17.11), we could posit a third structure with both PATIENT and InSTRUMENT, "to play [a sound] [on an instrument]." 
Although my study adds evidence to Muraoka's data, there is little that is surprising in comparison to the Hebrew used in the Bible. The verb בוא, "to come," for example, takes the same argument structure-THEME and LOCATIONin the Hebrew of the Bible, with the same range of possibilities for the type of phrase used for LOCATION: NP, אל-PP, ב-PP, ל-PP, עד ב-P.59 To give another example, עשה, when it has the sense of behaving or acting in a certain manner, has the same argument structure in $1 \mathrm{QM}$ as in the Hebrew found in the Bible.

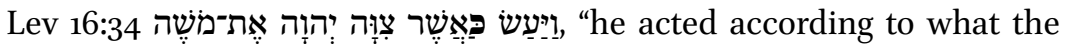
LORD commanded Moses"

1QM 10:8 יעשה כמעשיכה הגדולים, "wwho] can act according to your great deeds?"

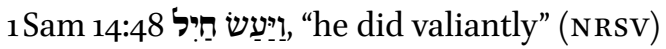

1QM 16:1 יעשה גבורז "he will act [according to] strength"

Hifil נפל, "to fell," provides an example of one of the few slight developments.

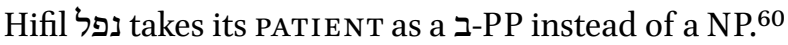

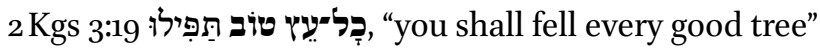

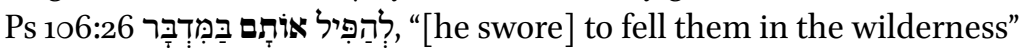

1QM 16:8 "להפיל בחללי כתיים "they shall begin] to fell the slain of the Kittim"

Though related to argument structure, this is not a development in argument structure strictly speaking, since the verb still takes an AGENT and a PATIENT. ${ }^{61}$ Hebrew before the Dss already makes similar use of ב-PPs to mark complements. ${ }^{62}$

Some binyanim (e.g., Hitpael קרב) are not used in the Hebrew Bible, but their argument structure clearly aligns with the argument structure of the same root in other binyanim used in the Hebrew of the Bible.

59 See, e.g., Gen 45:25 (NP), Gen 6:18 (אל-PP), 1 Kgs 14:17 (ב-PP), 2 Sam 5:23 (ל-PP), and Gen 11:31 (עד-PP).

6o Cf. Clines, Dictionary of Classical Hebrew, נפל. Though not involving a verb of instruction or comprehension, this development appears to be related to the development of discussed by Rey, "Prepositional Object with bet."

$61 \quad$ See section 2 and footnote 29 .

62 Rey, "Prepositional Object with bet," 19o. For example, D חז "to strengthen" with Patient only as a NP, but H חזק "to strengthen" with PATIENT as a NP or בPP (both in the Bible and Dss); cf. Muraoka, "Verb Complementation in Qumran Hebrew," 117. 
Most of 1 QM's verbs, then, behave in the same way they behave in the Hebrew Bible. Rather than hiding the continuity with preceding Hebrew and focusing on ways in which the Hebrew of the Scrolls is different, I think the continuity is worth highlighting - indeed it must be highlighted. Though the prevailing focus in Dead Sea Scrolls scholarship falls on what is different in the Scrolls, it is equally important to note and chart out continuities and similarities. ${ }^{63}$ In addition to presenting the evidence clearly and accurately, a focus on continuity can have significant impact on how we view the language of $1 \mathrm{QM}$ and the Scrolls - a point I return to in my conclusion.

\section{Implications and Conclusions}

More research on the argument structures of verbs in ancient Hebrew textsin the Bible and the Dead Sea Scrolls-is needed. Concerning the Scrolls in particular, Muraoka's important study included data from only a handful of Scrolls, and there is some flexibility in the interpretation of the data. And while the present study has argued for a different method and provided data and an example, much more space is needed to fully flesh out the profile of a single text like 1QM. Such studies are how we will fully chart the nature and development of the Hebrew language.

In the areas of language that I have considered extensively in $1 \mathrm{QM}$ - the syntax of the noun phrase, ${ }^{64}$ word order, ${ }^{65}$ and verbal argument structure, as well as numeral syntax, which I have considered in all of the Scrolls ${ }^{66}$-I see little development from earlier periods of Hebrew. There are few cases where verbal argument structure has developed from the Hebrew found in the Bible to the Hebrew of the Scrolls, correlating with what I have seen with other areas of language. This is a positive outcome. Each text, and its language, is worthy of study in its own right, even if the results do not give us anything different to contrast with biblical texts and language. More importantly, the linguistic continuity of 1 QM with earlier texts must be explained. Either the native language of 1 QM's author(s) is substantially the same as earlier Hebrew, or $1 \mathrm{QM}$ is classicizing. While I think the classicizing explanation is more likely, it remains important to recognize and highlight the many ways in which the Hebrew of the Scrolls is in line with Hebrew we find in the texts of the Bible. It is also interesting to

\footnotetext{
63 See Screnock, "Hebrew in the Dead Sea Scrolls," 59, 85.

64 Holmstedt and Screnock, "Noun Phrase."

65 Screnock, "Word Order in the War Scroll."

66 Screnock, "Hebrew in the Dead Sea Scrolls."
} 
ask whether 1QM classicizes well, or whether it is inconsistent and makes mistakes. A major point in the debate about Hebrew diachrony, and its application to dating texts, is the extent to which a later text can imitate earlier Hebrew. Is it possible, or must the language always show some slip-ups? The more features we chart for $1 \mathrm{QM}$ and other texts, the better idea we get of the answer to this question.

\section{Bibliography}

Aarts, Bas. English Syntax and Argumentation. 2nd ed. Palgrave Modern Linguistics. London: Palgrave, 2001.

Brown, Francis, S.R. Driver, and Charles A. Briggs. The New Brown-Driver-Briggs HebrewEnglish Lexicon. Peabody, MA: Hendrickson, 1979.

Carnie, Andrew. Syntax: A Generative Introduction. 3rd ed. Oxford: Wiley-Blackwell, 2013.

Clines, David, ed. Dictionary of Classical Hebrew. Nine volumes. Sheffield: Sheffield Phoenix Press, 1993-2016.

Cook, John. "Valency: The Intersection of Syntax and Semantics." Pages 53-66 in Contemporary Examinations of Classical Languages (Hebrew, Aramaic, Syriac, and Greek): Valency, Lexicography, Grammar, and Manuscripts. Edited by Timothy Lewis, Alison Salvesen, and Beryl Turner. Perspectives on Linguistics and Ancient Languages 8. Piscataway, NJ: Gorgias, 2016.

Cook, John. "Verb Valency Lexicon." Unpublished electronic resource, created as part of Accordance Bible Software, 2010.

Cowper, Elizabeth. A Concise Introduction to Syntactic Theory:The Government-Binding Approach. Chicago: University of Chicago Press, 2009.

Holmstedt, Robert D., and John Screnock. "Writing a Descriptive Grammar of the Syntax and Semantics of the War Scroll (1QM): The Noun Phrase as Proof of Concept." Pages 67-106 in The War Scroll, War and Peace in the Dead Sea Scrolls and Related Literature. Edited by Kipp Davis et al. STDJ 115. Leiden: Brill, 2015.

Holmstedt, Robert, John Cook, and Phillip Marshall. Qohelet: A Handbook on the Hebrew Text. Waco, Tx: Baylor University Press, 2017.

Holmstedt, Robert. Ruth: A Handbook on the Hebrew Text. Waco, Tx: Baylor University Press, 2010.

Jackendoff, Ray. "The Status of Thematic Relations in Linguistic Theory." Linguistic Inquiry 18 (1987): 369-411.

Koehler, Ludwig, Walter Baumgartner, and Johann J. Stamm. The Hebrew and Aramaic Lexicon of the Old Testament. Translated and edited under the supervision of Mervyn E.J. Richardson. 4 vols. Leiden: Brill, 1994-1999. 
Lowe, John. Transitive Nouns and Adjectives: Evidence from Early Indo-Aryan. Oxford: Oxford University Press, 2017.

Malessa, Michael. "Valency." Pages 893-96 in Encyclopedia of Hebrew Language and Linguistics, Volume 3: P-Z. Edited by Geoffrey Khan et al. Leiden: Brill, 2013.

Malessa, Michael. Untersuchungen zur verbalen Valenz im biblischen Hebräisch. Studia Semitica Neerlandica 49. Assen, The Netherlands: Van Gorcum, 2006.

Muraoka, Takamitsu. "An Approach to the Morphosyntax and Syntax of Qumran Hebrew." Pages 193-214 in Diggers at the Well: Proceedings of a Third International Symposium on the Hebrew of the Dead Sea Scrolls and Ben Sira. Edited by T. Muraoka and J.F. Elwolde. STDJ 36. Leiden: Brill, 2000.

Muraoka, Takamitsu. “On Verb Complementation in Biblical Hebrew.” VT 29 (1979): 425-35.

Muraoka, Takamitsu. "Verb Complementation in Qumran Hebrew." Pages 92-149 in The Hebrew of the Dead Sea Scrolls and Ben Sira: Proceedings of a Symposium held at Leiden University 11-14 December 1995. Edited by T. Muraoka and J.F. Elwolde. STDJ 26. Leiden: Brill, 1997.

Polak, Frank. "Verbs of Motion in Biblical Hebrew: Lexical Shifts and Syntactic Structure." Pages 161-97 in A Palimpsest: Rhetoric, Ideology, Stylistics, and Language Relating to Persian Israel. Edited by Ehud Ben Zvi, Diana Edelman and Frank Polak. PHSC 5. Piscataway, NJ: Gorgias, 2009.

Primus, Beatrice. Cases and Thematic Roles: Ergative, Accusative and Active. Berlin: De Gruyter, 2010.

Qimron, Elisha. A Grammar of the Hebrew of the Dead Sea Scrolls. Jerusalem: Yad Izhak Ben-Zvi, 2018.

Rey, Jean-Sébastien. "On the Prepositional Object with bet in Ben Sira and the Dead Sea Scrolls." Pages 189-213 in Hebrew in the Second Temple Period: The Hebrew of the Dead Sea Scrolls and of Other Contemporary Sources. Edited by Moshe Bar-Asher, Steven Fassberg and Ruth Clements. STDJ 108. Leiden: Brill, 2013.

Screnock, John. "Word Order in the War Scroll (1QM) and Its Implications for Interpretation." DSD 18 (2011): 29-44.

Screnock, John. “The Syntax of Complex Adding Numerals and Hebrew Diachrony." JBL 137 (2018): 789-819.

Screnock, John. "Assessing the Character of Hebrew in the Dead Sea Scrolls: Historical Linguistics, Numeral Syntax, and the Notion of a Distinct 'Dead Sea Scrolls' Hebrew." Pages 59-91 in Dead Sea Scrolls, Revise and Repeat: New Methods and Perspectives on the Dead Sea Scrolls. Edited by Carmen Palmer et al. SBLEJL 52. Atlanta: SBL Press, 2020.

Screnock, John, and Robert Holmstedt. Esther: A Handbook on the Hebrew Text. Waco, TX: Baylor University Press, 2015.

Van der Merwe, Christo, Jackie Naudé, and Jan Kroeze. A Biblical Hebrew Reference Grammar. Biblical Languages: Hebrew 3. Sheffield: Sheffield Academic, 1999. 